UDC 025.3(574)

MANABAT A. R.

Nazarbayev University Library (Nur-Sultan, Kazakhstan), e-mail: april.manabat@ nu.edu.kz, ORCID 0000-0003-1720-5910

\title{
DOCUMENTING THE CATALOGING PRACTICES AND POLICIES AMONG SELECTED LIBRARIES IN KAZAKHSTAN
}

Objective. A survey was conducted among selected librarian catalogers in Kazakhstan to determine the current cataloging practices and policies being employed in their respective libraries. Methods. Responses suggested that cataloging is still one of the important aspects of the library work even with the emergence of electronic resources. Results. While many were still applying traditional standards such as MARC, AACR, LC and DDC in their descriptive cataloging and authority works, catalogers were interested in new standards such as RDA and BIBFRAME. Conclusions. Finally, interests in having a unified online catalog as well as more trainings on the field of cataloging and metadata librarianship in the future has also been considered by these libraries to improve the quality of their cataloging work.

Keywords: cataloging practices; Kazakhstan

\section{Introduction}

Cataloging and classifying materials are some of the technical works usually done by librarians to facilitate easy access and retrieval of library collections. Though cataloging might be an unpopular task to some librarians due to its tedious and detailed-oriented nature, a significant number of professionals still actively performed this work. Even in Kazakhstan, librarians still posit a considerable interest in this task and it is still worth investigating to understand what Kazakh catalogers are currently doing.

Most libraries in Kazakhstan based their cataloging practices on SIBID and Russian cataloging standards which needs to be updated and upgraded to reflect international changes and trends in creating bibliographic records (Bakhturina, 2016; Tukubayeva, 2018). These changes and trends also take advantage of technology as a tool to facilitate easy access and retrieval of materials. And with the emergence of online resources, the need to have an updated cataloging standards, practices and policies should also be considered.

Objectives. This study employed a descriptive approach to determine the existing cataloging practices and policies among selected libraries in Kazakhstan. Moreover, it also intends to identify the different ways on how Kazakhstani libraries are dealing with bibliographic records and metadata and how are they coping with the changing user behaviors and the emerging trends in the field of metadata librarianship. In addition, it seeks to examine the various ways on how to further improve the skills in cataloging and classification in the digital era.

\section{REVIEW OF RELATED LITERATURE}

There have been a number of studies conducted documenting cataloging practices and policies as well as how librarians embraced metadata librarianship around the world. One such study was conducted by Jin Ma (2009) assessing the current metadata practices of 68 Association of Research Libraries (ARL) member libraries using the SPEC Kit 298: Metadata. Her study revealed how libraries were embracing metadata librarianship with the evolution of digital collections and the changing user needs. Though the study has some limitations, it nonetheless provide a big picture of how the cataloging practices and policies evolved. Another study on cataloging and metadata practices, which was conducted by the Virtual Resources Association 
(2017), revealed that the respondents were gradually using new standards such as RDA and Dublin Core while still using the conventional ones such as AACR, LCSH among others. They were also embracing new trends in the field such as metadata librarianship and believed that new skills were still needed on creating bibliographic descriptions of materials.

A study by Hider (2014) also documents the contemporary cataloging policy and practice among Australian libraries. In his survey of 40 Australian libraries, catalogers still find the need to create records of online resources despite a growing interest of creating and maintaining merged catalogues or bibliographic databases. In addition, even with the emergence of online resources and tools, the cataloging skills still found to be very much relevant.

A comparison of the cataloging practices in university libraries in three developing Asian countries was the main focus of the study by Muhammad Khalid, Mahmood, and Wilson (1997). In their study, they examined the various similarities and differences of cataloging practices in universities from Pakistan, Malaysia, and Saudi Arabia. This includes the various cataloging standards and tools used, forms of catalogues among others. All three countries have a majority of Muslim population speaking Arabic, and libraries in these countries housed a large amount of collections in Arabic. The study revealed that university libraries in these countries have an overall uniformity with regards to cataloging tools, which can be used as a starting point for an international library cooperative cataloging activity. In addition, the emergence of technology paved the way to creation of new access points to facilitate easy retrieval and access (Muhammad Khalid, Mahmood, \& Willson, 1997).

Cataloging skill is one such unique skill that every librarian should learn. Unique as it seems, this skill also have some challenges and one such challenge is dealing with language. Joachim (2010) presented some of the challenges and difficulties that catalogers faced when describing materials on various languages. Aside from languages issues, poor bibliographic publication issues, name authority problems, problems with descriptive cataloging such as lack of chief sources of information, uniform titles, and copyright dates, inadequacy of subject headings and classification schedules, transliterations, as well as backlogs and cooperative cataloging should also be addressed (Joachim, 2010).

\section{Cataloging Practices in the CIS Countries}

Catalogers from CIS (Commonwealth of Independent States) countries also deal with some issues on describing materials. One such issue was the linguistic turmoil on describing "exotic" languages such as Serbo-Croatian (Cyrillic) and Turkic languages (Husic, 2008; Jajko, 1993). With the independence of some Central Asian states in 1990s, some CIS countries has decided to adopt officially the Roman script. However, catalogers were left with little guidance on how to describe materials in Cyrillic languages as the standards such as the Anglo-American Cataloging Rules (AACR) and USMARC were designed for English or other western languages especially with regards to authority control and title changes (Husic, 2008). In addition, the incorrect vocalization of these languages may also affect the meaning of the text, even filing of the entry, thus its retrievability (Jajko, 1993). With some fundamental changes initiated by the Library of Congress (LOC) in 2000, integrating formats such as internet sources does not require retaining information about former names, thus adopting the new language being used (Husic, 2008). Aside from language and description issues, Jajko (1993) also pointed out some identity problems about cataloger working as bibliographer especially in the Middle East to cater to these languages.

Language issues with regards to cataloging Central Asian materials was also evident in an article written by Walter (2010) where he discussed the challenges in describing some Tibetan, Mongolian, Kazakh, and other Central Asian Turkic works. Though he finds it interesting and 
enjoyable describing these kind of materials, he also faced some problems such as lack of vernacular reference and bibliographical sources for assigning the creator or authority files, shelflisting and assigning cutter numbers, and the application of uniform titles for literary works, as well as lack of consistency and specificity in the subject headings in addition to the adoption of new language chosen by some countries due to the breakup of the Soviet Union (Walter, 2010).

Aside from language issues, the importance of a unified approach to standardized cataloging practices as well as determining various ways of improving bibliographic description based on current trends is also being considered by some CIS libraries. With the current trends in the cataloging policies not to mention the emergence of new technologies and the social needs of the community, there is a need to look back on the historical developments of bibliographical description to create a more unified and standardized approach (Tukubayeva, 2018). Just like other CIS libraries, Kazakh libraries should also be open to such trends by gaining more knowledge and sharing best practices with foreign colleagues in the field (Tukubayeva, 2018).

\section{Methods}

Cataloging, though might be unpopular for some librarians due to its detailed-oriented nature, is still one of the technical skills that every librarian should learn. This study employed a descriptive approach to determine the existing cataloging practices and policies among selected libraries in Kazakhstan. The respondents of the study were the heads of the cataloging department or the head of the library or its authorized representative. The survey was sent to 20 libraries of different types (e.g. school, academic, special, public). Out of 20 libraries, only 9 libraries responded to the survey. To maintain anonymity of these libraries, a simple coding system will be used.

A 21-item structured online questionnaire were sent to selected Kazakhstani libraries. The questions were adopted from the study of Hilder (2014). These questions were about their cataloging practices and policies such as the use of integrated library systems, availability of online public access catalogs (OPACs), employing and adopting standards such as MARC, RDA among others. In addition, their experiences with cataloging online resources as well as their perception on conducting cataloging-related trainings and seminars as well as the establishment of a union catalog was also explored. Aside from English, questionnaires in Russian and Kazakh languages were also sent to the respondents to ensure that they can answer the questionnaire in whatever language they are comfortable with. Graphs and percentages were used to analyze their responses.

This study, including the consent and survey form, was approved by the Nazarbayev University Institutional Research Ethics Committee (NU-IREC).

\section{Results and Discussion}

\section{Profile of Selected Kazakhstani Libraries}

Out of 20 libraries, only nine (9) libraries responded to the online survey. To maintain anonymity, a coding system was used as noted on Table 1 . Among nine libraries, five of them were from academic library, two from school library and one from the public library. Seven of them were located in Nur-Sultan, the capital city of Kazakhstan while two of them were situated in Almaty, the old capital. 
Profile of Selected Kazakhstani Libraries

\begin{tabular}{|c|c|c|}
\hline Library & Type of Library & Location \\
\hline A & Academic & Almaty \\
\hline B & Academic & Nur-Sultan \\
\hline C & School & Nur-Sultan \\
\hline D & School & Nur-Sultan \\
\hline E & Public & Nur-Sultan \\
\hline F & Academic & Nur-Sultan \\
\hline G & Academic & Almaty \\
\hline H & Academic & Nur-Sultan \\
\hline I & Academic & Nur-Sultan \\
\hline
\end{tabular}

\section{The ILS and the Library Catalog}

The library catalog serves as the index to the library collection. With the advancement of technology, a shift from the traditional $3 \times 5$ catalog cards to the computerized online library catalog has been implemented for years. Having an automated or integrated library system (ILS) will be very much helpful to implement this. Table 2 below shows that almost all of libraries surveyed have their own ILS which is a proprietary one while a lone library doesn't have any. In addition, only six of these libraries have a web-based or online public access catalog (OPAC) and can be accessed through a dedicated interface.

Table 2

\section{Profile of Selected Kazakhstani Libraries based on ILS and OPAC}

\begin{tabular}{|c|c|c|c|}
\hline Library & With ILS & $\begin{array}{c}\text { ILS (X-in-house; } \\
\text {-commercial) }\end{array}$ & With OPAC \\
\hline A & X & X & X \\
\hline B & $\sqrt{ }$ & $\sqrt{ }$ & $\sqrt{ }$ \\
\hline C & $\sqrt{ }$ & $\sqrt{ }$ & X \\
\hline D & $\sqrt{ }$ & $\sqrt{ }$ & $\sqrt{ }$ \\
\hline E & $\sqrt{ }$ & $\sqrt{ }$ & $\sqrt{ }$ \\
\hline F & $\sqrt{ }$ & $\sqrt{ }$ & $\sqrt{ }$ \\
\hline G & $\sqrt{ }$ & $\sqrt{ }$ & $\sqrt{ }$ \\
\hline H & $\sqrt{ }$ & $\sqrt{ }$ & ( \\
\hline I & $\sqrt{ }$ &
\end{tabular}

In addition, almost all of these libraries have their physical collections represented or searchable in their OPAC. However, only four of them have all their online collections searchable in their online catalog, three of them have only selected online collections in their catalog, one doesn't use it for their online collection, and lastly, a lone respondent doesn't have their online collection at all. 


\section{Cataloging Standards}

Employing various cataloging standards is very much essential for any cataloging work. These standards ensure consistency with regards to the cataloging practices, procedures, and policy being employed in the library. On employing standards, only five libraries said that their catalogue records were based on MARC standards. Four of these libraries were based on other standards such as the RUSMARC and LBC. Figure 1 shows that $50 \%$ of these libraries employ Russian Cataloging Standards such as RUSMARC while some also use the usual cataloging standards or schemes like the Library of Congress Classification Scheme (LCSH) and the Dewey Decimal Classification Scheme (DDC). In addition, seven libraries $(77.78 \%)$ indicated that the source of their catalog records were mainly in-house original cataloging done by professional librarians (77.78\%) and copy-cataloging done also by professional librarians (66.67\%) and sometimes alongside with the library technicians (33.33\%) as noted on Figure 2.

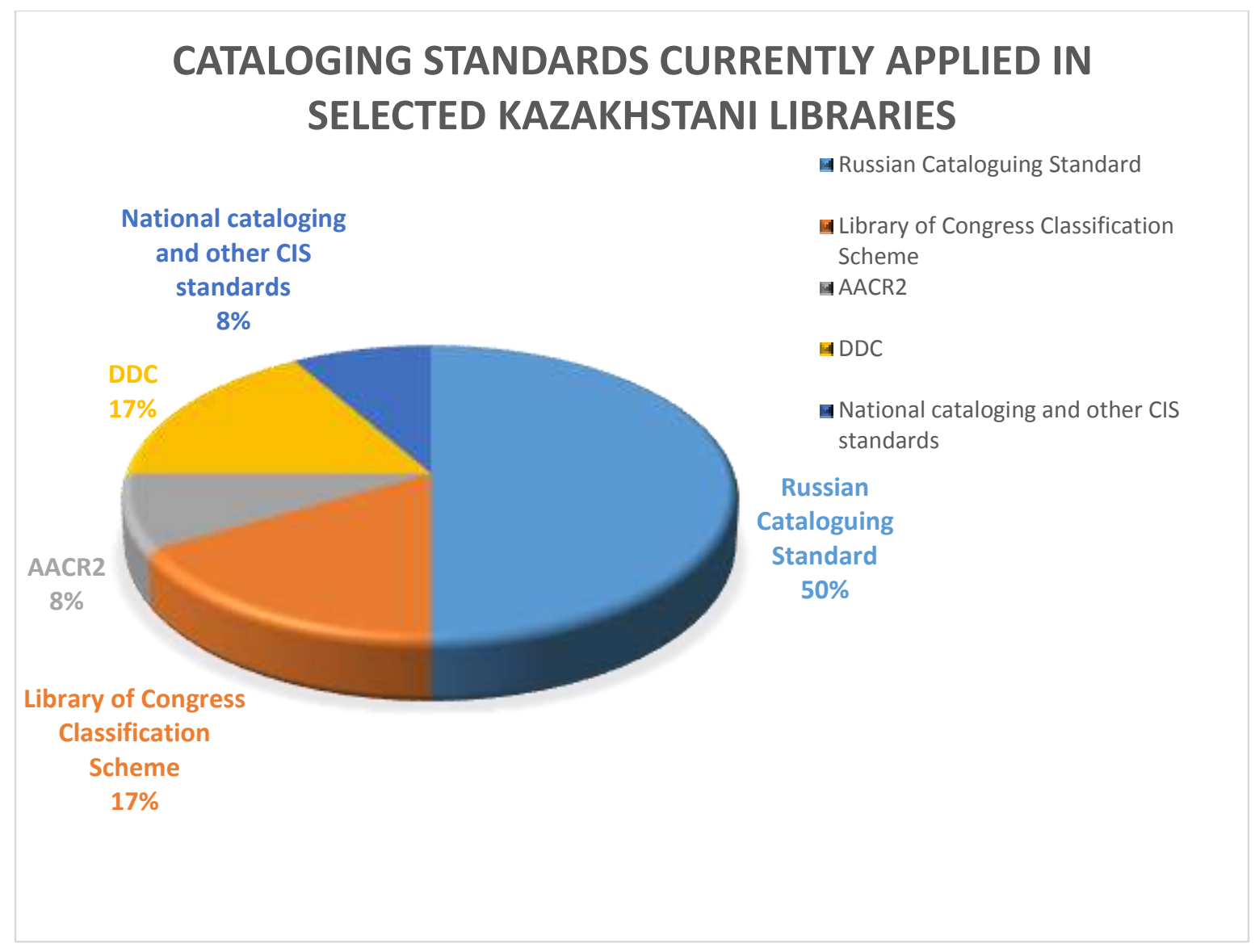

Fig. 1. Cataloging Standards in Selected Kazakhstani Libraries 


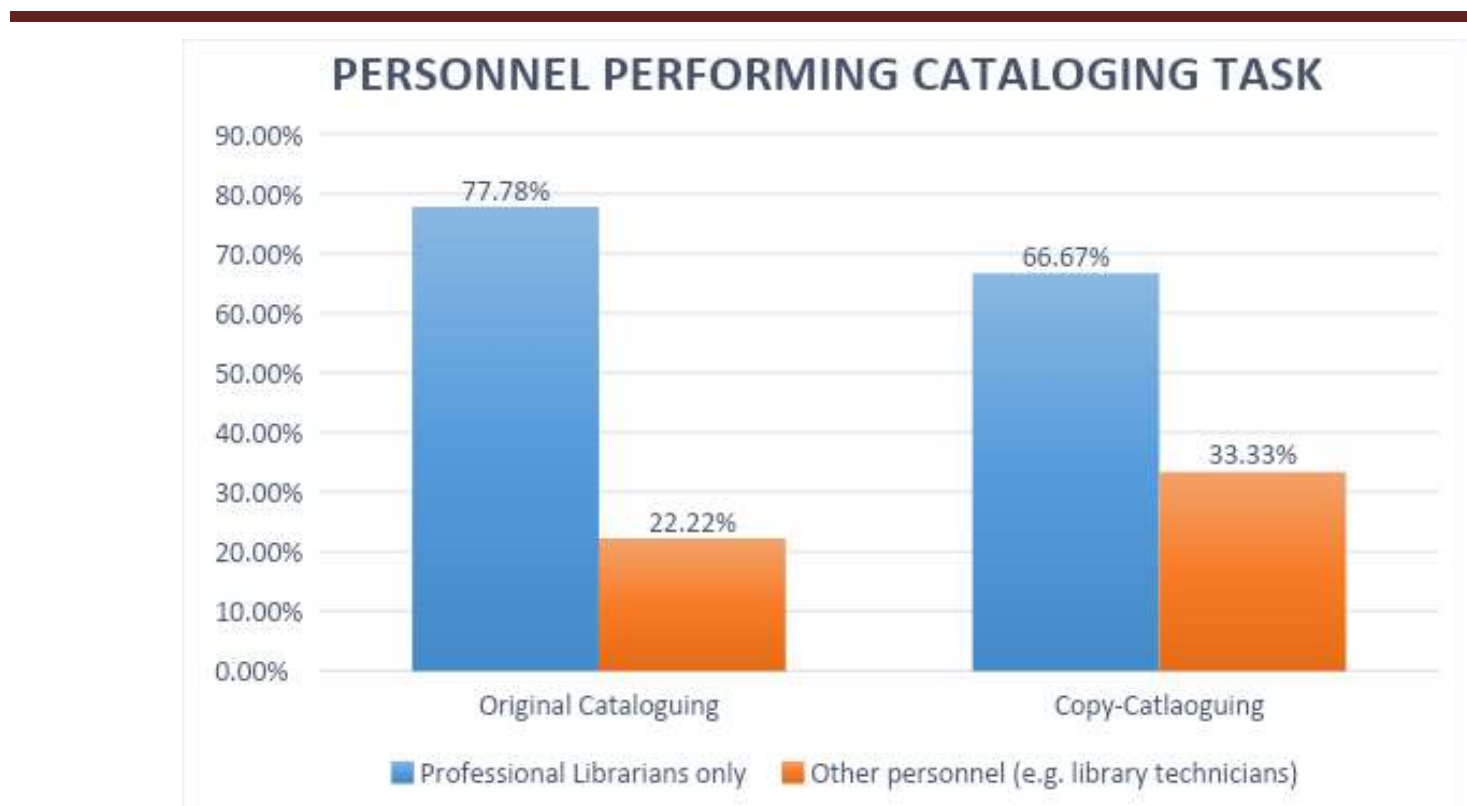

Fig. 2. Personnel Performing Cataloging Task

Authority control is also a practice in the cataloging work in these selected Kazakhstani libraries. Out of 9 libraries, $6(66.67 \%)$ libraries said that authority control was being carried out in their respective libraries to ensure consistency on their bibliographic records. As for adoption of Resource Description and Access (RDA), only a lone respondent said that they were on the process of adopting it while two other libraries said that they plan to adopt it in the coming years. Interestingly, though RDA has been a talk of the town for a quite some time now especially in many libraries around the globe, two more libraries have no plans to adopt it while the four other libraries do not have any idea on when they will adopt RDA.

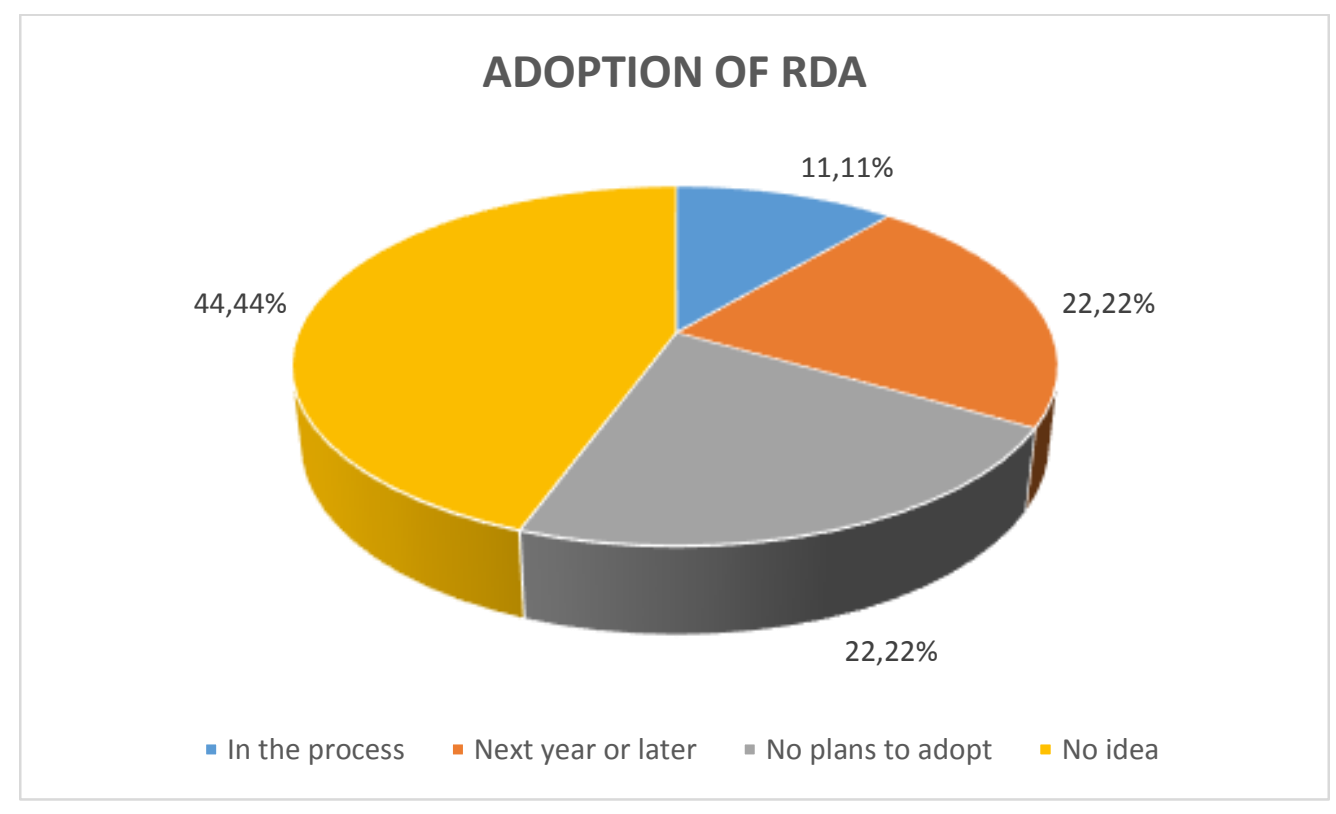

Fig. 3. Adoption of RDA 


\section{Cataloging Practices and Future Plans}

For the past years, these selected Kazakhstani libraries have observed an increasing amount of cataloging work. With the introduction of technology and the emergence of various library materials and formats including electronic resources, catalogers have tried to remain relevant to the changing needs of the time. Majority of these libraries $(44.44 \%)$ have started digital resource cataloging for the past five years, which includes creating or importing catalogue records.

In addition, some of the cataloging knowledge and skills that are currently practiced by selected Kazakhstani libraries were also determined. Most of these libraries (66.67\%) employ MARC standards in there cataloging work. They also implement descriptive, serial, and digital resource cataloging as well as the Library of Congress Classification Scheme. Given that most libraries are now embracing a more Western approach in their cataloging work, it was interesting to know that there were few libraries that employ some CIS-related cataloging standards, such as RUSMARC, as noted on Figure 4.

\section{Knowledge and Skills Currently Practice in Selected Kazakhstani Libraries}

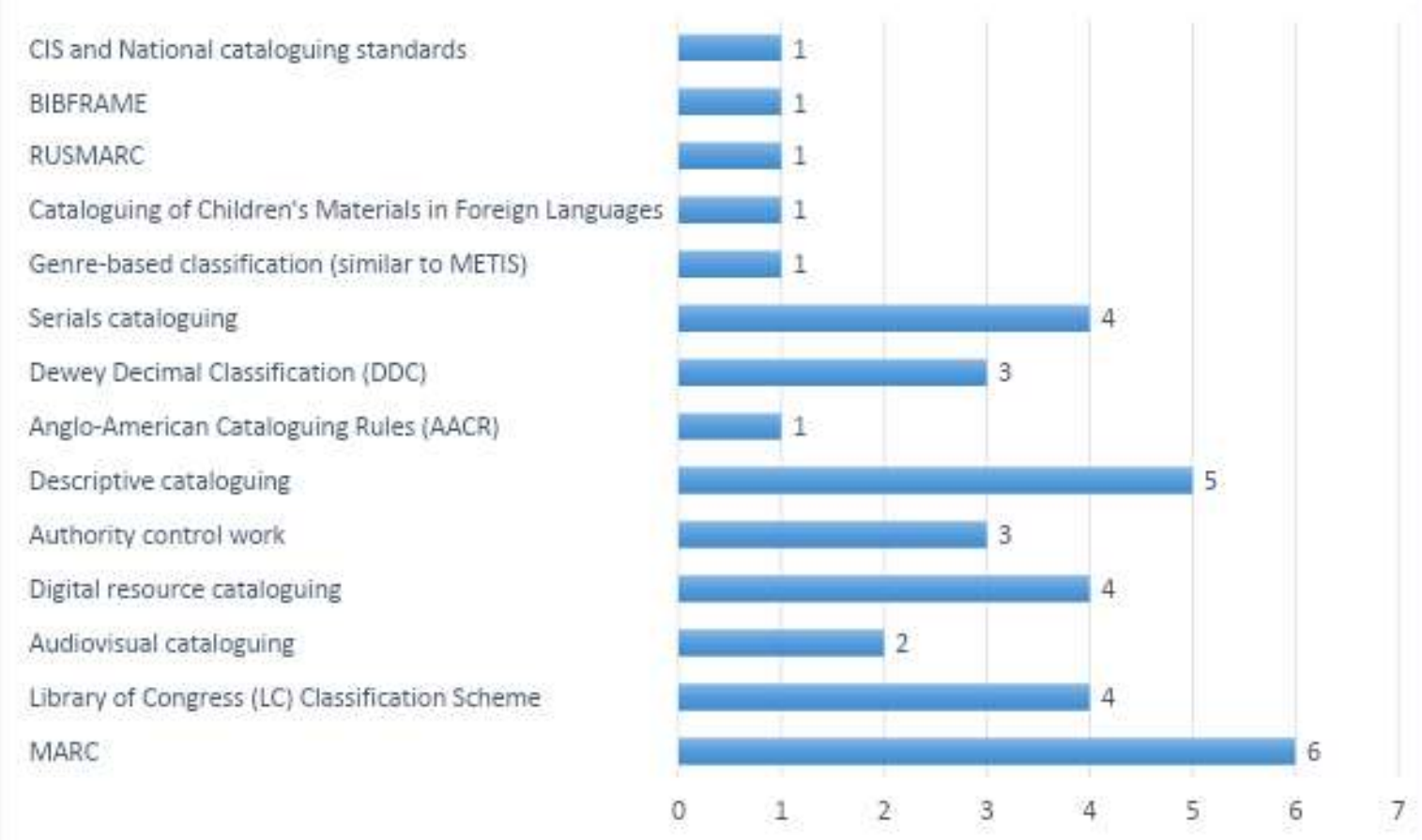

Fig. 4. Current Cataloging Practices Employed by Selected Kazakhstani Libraries

With regards to the use of language, most of these libraries use the language of the material and provide parallel titles in English, Kazakh, and/or Russian. An area in the bibliographic records also shows the language of the material. The subject assigned is also in the language of the material. However, the fields are written in English language as noted in Figure 5. 


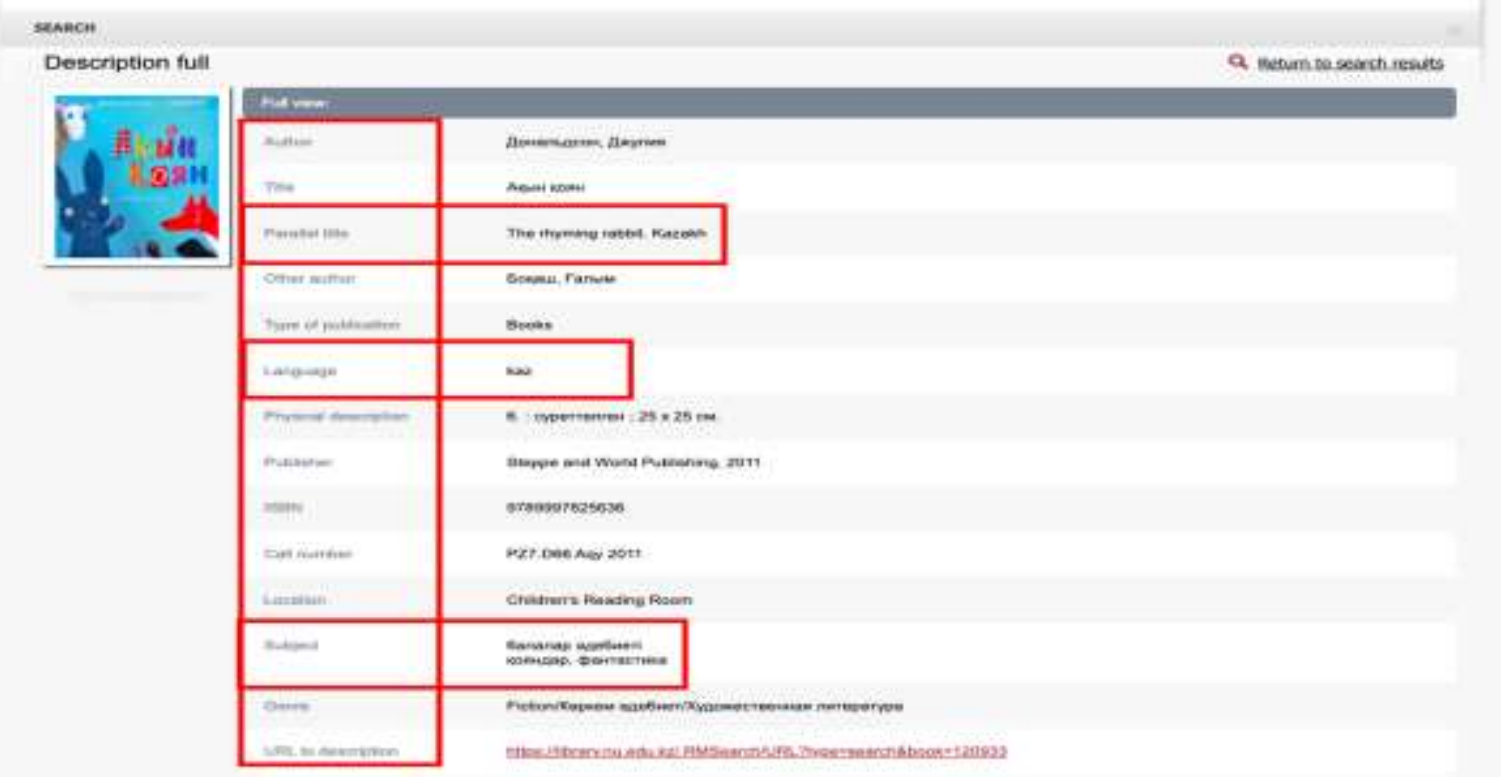

Fig. 5. A sample catalog record

While some respondents noted that there were cataloging knowledge and skills that are currently in place in their respective libraries, they also identified some areas that need to be learned and improved by cataloging staff as presented on Figure 6. Most of these libraries noted that skills in digital resource (55.56) and audiovisual cataloging (55.56\%) need to be learned or improved by cataloging staff. Knowledge and skills on the use of Library of Congress Classification Scheme (44.44\%) as well as MARC rules (44.44\%) were also determined as areas for improvement. Although RDA has been in place for so many years now in majority of the libraries around the world, only three of these nine libraries noted RDA as one of the areas that they think needs to be learned or improved.

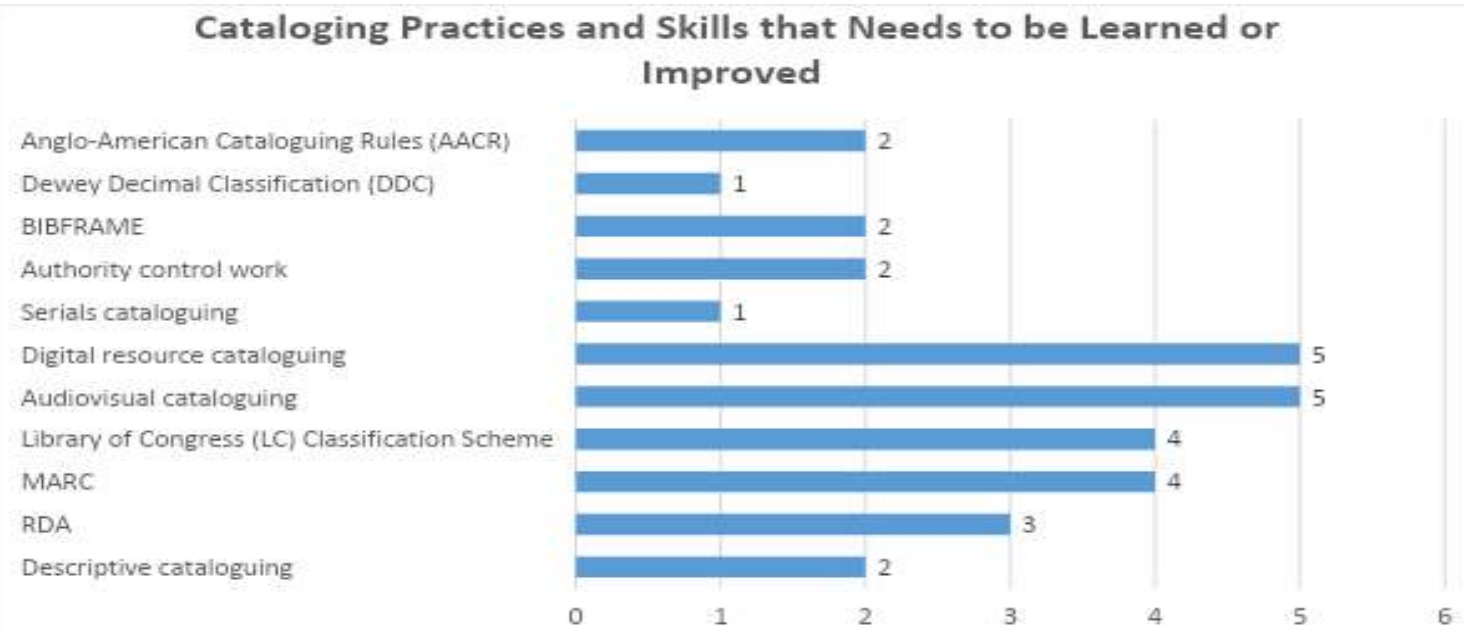

Fig. 6. Areas of Cataloging Practices to be Learned or Improved by Selected Kazakhstani Libraries 
Plans for improvement of their cataloging practices and policies of these selected Kazakhstani libraries were also considered. Most of these libraries focus their plans towards acquiring a new automated library system and creating the online bibliographic records of their library collection to facilitate easy access and retrieval. This also includes consistency of the records and converting their classification scheme from DDC to LC. Digitization plans were also on their priority list as well as continuous cataloging of library materials and increasing the volume of their library collection. One library noted that its focus was on training its librarian catalogers and equipping them to be more knowledgeable on the current trends on the cataloging and classification work.

In addition to their ongoing plans, majority of these libraries (77.78\%) were open to the possibility of conducting some cataloging-related trainings and workshops among Kazakhstani libraries. However, only five of them were interested in establishing a union catalog.

\section{Conclusions}

Cataloging work might be one of the least popular and appealing tasks for many librarians due to so much attention to details. With the advent of technology as well as the introduction of various cataloging standards and other guidelines to ensure consistency of the bibliographic records and the cataloging work in general, librarian catalogers find themselves struggling and challenged on how to adopt these kind of standards and make them work in the furtherance of the goals. Kazakhstani librarians also faced the same challenges not only when adopting a more Western approach to this work but also when using the native language. Despite this, Kazakhstani librarians remain open to various possibilities and opportunities to learn and improve their cataloging work.

\section{REFERENCES}

Bakhturina, T. (2016). SIBID standards at the beginning of the XXI century: Renovation and expansion of information. Scientific and Technical Libraries, 5, 59-76. doi: https://doi.org/10.33186/1027-36892016-5-59-76 (in Russian)

Hider, P. (2014). Contemporary cataloging policy and practice in Australian libraries. Australian Academic \& Research Libraries, 45(3), 193-204. doi: https://doi.org/10.1080/00048623.2014.920568 (in English)

Husic, G. (2008). Orthographic reforms in the former Soviet Union: some implications for serials and internet resource catalogers. Slavic East European Information Resources, 2(2), 35-46. doi: https://doi.org/10.1300/J167v02n02 (in English)

Jajko, E. A. (1993). Cataloging of Middle Eastern materials (Arabic, Persian, and Turkish). Cataloging \& Classification Quarterly, 17(1-2), 133-148. (in English)

Joachim, M. (2010). Issues and problems in cataloging the languages of the world. Cataloging \& Classification Quarterly, 17(1-2), 1-14. (in English)

Ma, J. (2009). Metadata in ARL libraries: A survey of metadata practices. Journal of Library Metadata, 9(1-2), 1-14. doi: https://doi.org/10.1080/19386380903094977 (in English)

Muhammad Khalid, H., Mahmood, K., \& Willson, J. (1997). Cataloging practice in university libraries:A comparison of three developing countries (Pakistan, Malaysia, Saudi Arabia). Library Review, 46(5), 328-338. doi: https://doi.org/10.1108/00242539710178461 (in English)

Tukubayeva, K. (2018). Bibliographic description of documents in the historical context. Proceedings of the 7th International Conference on Emerging Global Trends in University Library Development (Library Connect 2018), 107-114. (in English) 
Virtual Resources Association. (2017). Cataloging and metadata practices survey report. Retrieved from https://cutt.ly/LR3Dukw (in English)

Walter, M. (2010). Central Asian cataloging. Cataloging \& Classification Quarterly, 17(1-2), 149-158. (in English)

MANABAT A. R.

Бібліотека Університету Назарбаєва (м. Нур-Султан, Казахстан),

e-mail: april.manabat@nu.edu.kz, ORCID 0000-0003-1720-5910

\section{ДОКУМЕНТУВАННЯ ПРАКТИКИ ТА ПОЛТТИИ КАТАЛОГІЗАЦЇ̈ СЕРЕД ВИБРАНИХ БІБЛІОТЕК КАЗАХСТАНУ}

Мета. 3 метою визначення сучасної практики та політики каталогізації, що застосовуються у бібліотеках, було проведено опитування серед обраних бібліотекарів-каталогізаторів Казахстана. Методика. Після аналізу відповідей, можна припустити, що каталогізація все ще є одним із важливих аспектів роботи бібліотеки, навіть із появою електронних ресурсів. Результати. Хоча багато хто досі застосовує традиційні стандарти, такі як машиночитна каталогізація (MARC), Англо-американські правила каталогізації (AACR), набір стандартів Американської бібліотечної асоціації - Бібліотеки Конгресу (LC) та Десяткову класифікацію Дьюї (DDC), у своїх описових каталогізаціях та авторитетних роботах, каталогізаторів зацікавили нові стандарти, такі як опис та доступ до ресурсу (RDA) та BIBFRAME. Висновки. Ці бібліотеки також були зацікавлені в створенні єдиного онлайн-каталогу та навчанні в галузі каталогізації та метаданих для покращення якості їх роботи з каталогізації.

Ключові слова: практики каталогізації; Казахстан

Received: 03.08.2021

Accepted: 01.12.2021 